the constancy of physical form. Although Hawthorne foregrounds the instability of material forms and thus overturns the materialist logic underwriting the aesthetic arguments of antebellum ethnology, he never disputes the legitimacy of racial hierarchies. Hawthorne ultimately opposes the appreciation of aesthetic beauty to the maintenance of a viewer's individuality - setting the moral instability of romance and Rome against the "simple daylight" of the United States-to establish a being's aesthetic nature as itself the clearest marker of racial inferiority.

\section{Abstract of "Re-membering a Nation Divided: War, Tourism, and the Making of the Modern Citizen"}

\author{
SUSAN SCHECKEL
}

State University of New York, Stony Brook thors brought to their subject. The guidebooks, in contrast, aimed for reproducibility. Inflecting the language of tourism with that of the pilgrimage, guidebooks to the United States Capitol helped to (mass-)produce an idea of the nation while simultaneously investing it with the power of the sacred. The language of pilgrimage these guidebooks used infused the nation with history while simultaneously urging citizentourists to venerate a nation ever in the making. According to the guidebooks, the fulfillment of history that justified the language of the sacred lay in the future, which the gaze of the citizentourist was to help create. Making the Capitol the occasion for national imaginings, these guidebooks nostalgically constructed a past that never was and a citizenry that emerged through the act of (guided) interpretation, in which the citizen was cast as audience and actor in the ongoing performance of "the nation." They thus set forth a model of citizenship flexible enough to withstand even the disruptions of war. 